\title{
Microgravity effect on expression of Raf kinase inhibitor protein on MCF-7 breast cancer cell line
}

\author{
Maryam Salavatifar ${ }^{1}$, Zahra Hajebrahimi $^{2}$ \\ 1. Assistant Professor, Aerospace Research Institute, Ministry of Science, Research and Technology, Tehran, Iran, Tel: 021- \\ 88366030, Email: salavati@ari.ac.ir, ORCID CD:0000-0003-0745-5967 \\ 2. Assistant Professor, Aerospace Research Institute, Ministry of Science, Research and Technology, Tehran, Iran
}

\begin{abstract}
Background and Aim: The living organisms on the earth are under the influence of natural gravity force and if this gravitational force changes, they will be affected by a unique shock. Weightlessness has important effects on cell function by interfering with biochemical pathways and gene expressions. Study of these changes would be of benefit to astronauts and can improve the quality of human life on earth. In simulated microgravity, the expression of some genes and protein levels produced in cultured cells or laboratory animals have been altered. However, very little information is available on the effects of microgravity on gene expression. Raf kinase inhibitory protein (RKIP) is a regulator of kinase

activity and a cell balancing agent that can act as a metastatic inhibitor in a variety of solid tumors, including breast cancer. In general, the RKIP expression in progressive tumors is reduced but its increased expression can result in reduced invasive potency of cancer cells without affecting primary tumor growth.

Materials and Methods: In this study, changes of RKIP gene expression were investigated in human MCF-7 breast cancer cells after 24 and 72 hours exposure to microgravity conditions using qReal time PCR method. We used t-test for data analysis and graphpad prism 7 project for plotting graphs.

Results: The results showed that microgravity changed gene expression of RKIP and led to increased expression levels of the gene after 24 hours exposure to microgravity.

Conclusions: By optimizing the duration of microgravity, we can observe significant changes in RKIP gene expression in MCF-7 cell line which can be considered promising for the treatment of cancer .
\end{abstract}

Keywords: Clinostat, Gravity, RKIP protein, Tumor

Received:Feb3,2019 Accpt:Oct5,2019

How to cite the article: Maryam Salavatifar,Zahra Hajebrahimi. Microgravity effect on

expression of Raf kinase inhibitor protein on MCF-7 breast cancer cell line. SJKU 2019; 24 (5): $42-55$

Copyright (C) 2018 the Author (s). Published by Kurdistan University of Medical Sciences. This is an open access article distributed under the terms of the Creative Commons Attribution-Non Commercial License 4.0 (CCBYNC), where it is permissible to download, share, remix, transform, and buildup the work provided it is properly cited. The work cannot be used commercially without permission from the journal. 


\title{
تأثير بیىوزنى بر بيان بروتئين مهار كننده كيناز Raf در رده سلولى MCF-7 سرطان يستان
}

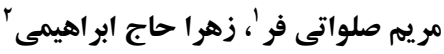

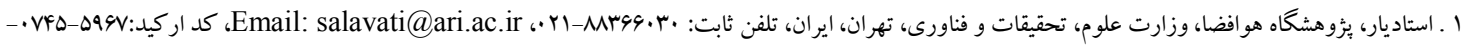 \\ ........r \\ r. استاديار، يُروهشكاه هو افضا، وزارت علوم، تحقيقات و فناورى، تهران، ايران
}

جكيده

زمينه و هدف: موجودات زنده در سطح زمين تحت تأثير نيروى گرانش طبيعى قرار دارند و جنانجه اين نيروى گرانش تغيير

نمايد، تحت تأثير شوكى منحصر به فرد قرار خواهند گرفت. بىوزنى از طريق مداخله با مسيرهاى بيوشيميايى و بيان زن، اثرات مهمى را بر عملكرد سلولها دارد و مطالعه اين تغييرات براى كمكك به فضانوردان و بهبود كيفيت زندكى انسان مفيد خو اهد بود. هدف از مطالعه؛ تعيين تأثير بىوزنى بر بيان يروتئين مهار كننده كيناز Raf در رده سلولى MCF-7 سرطان پِتان بود.

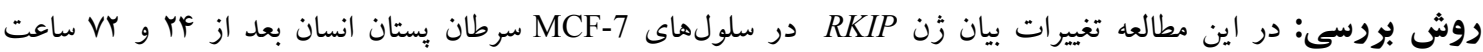
قرار گيرى در شرايط بى وزنى با روش qReal time PCR بررسى گرديد. آزمون t-test براى تجزيه و تحليل آمارى استفاده شد و نمودارها توسط برنامه 7 Graphpad prism رسم گرديد. يافته ها: نتايج نشان داد كه بى وزنى، بيان زٔن RKIP را تغيير داده و منجر به افزايش سطوح بيان آن پس از FF ساعت قراركيرى در شرايط بىوزنى گرديده است. نتيجه كيرى: با بهينه سازى مدت زمان تيمار بى وزنى شاهد تغييرات قابل توجه در بيان زن RKIP در رده سلولى MCF-7 خو اهيم بود، تا از اين طريق بتوان راه كارهايى رادر درمان سرطان ارائه نمود. واز كان كليدى: كلينواستت، جاذبه، يروتئين RKIP، تومور

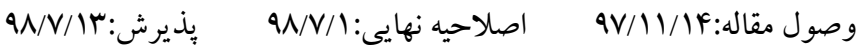


مراحل متاستاز شامل رگك زايى، تهاجم، ورود به رگك و كلونيزه شدن را محدود مىنمايد و افزايش بيان آن، بِنانسيل تهاجمى سلولهاى سرطانى يستان را بدون تأثير بر رشدشان كاهش داده است (1) كاو • (1). كليه موجودات ساكن بر كره زمين، تحت نيروى جاذبه قرار داشته و با اين نيرو تكامل و انطباق يافتهاند. با مطالعه موجودات و سلولها در شرايط حذف اين نيرو، برخى از ابهامات علم زيست شناسى مرتفع شده و حتى مىتوان در ارتقاء كيفيت حيات بر روى زمين و يا حتى ارسال حيات به كرات ديخر، كامهاى مؤثرى برداشت(Y I I). يافتهاى بيشين حاكى از آن هستند كه با حذف نيروى جاذبه، فرايندهاى

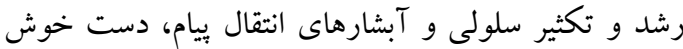
تغيير گرديدهاند و شرايط منحصر به فردى ايجاد گثته كه از طريق مطالعه آنها، برخى ساز و كارهاى سلولى به به نحو بهو

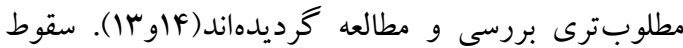
آزاد و يروازهاى فضايى، شرايطى هستند كه مىتوان با قرار دادن موجودات و يا سلولها در آن، بى وزنى را اعمال نمود؛ اما بى وزنى رخ داده در سقوط آزاد به دليل كوتاه بودن، تأثير قابل توجهى نخواهد داشت. از طرفى بروازهاى

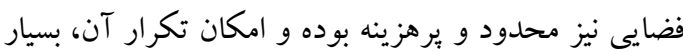
اندكك است. با توجه به موارد فوقالذكر، ابزارهاى شبيه ساز بى وزنى مورد اقبال قرار گرفته و مىتوان جهت مطالعات حذف نيروى جاذبه از آنها استفاده نمود(واوها). با توجه به موارد فوق، مطالعه حاضر به بررسى تأثير بىوزنى شبيه آنهاديه

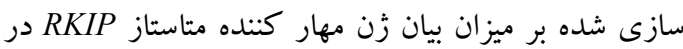
رده سلولى MCF-7 سرطان بِستان يرداخته است.

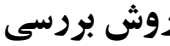

رشد و باساز سلولى: رده سلولى MCF-7 از مركز ملى بلى ذخاير زُنتيكى و زيستى ايران خريدارى شد. اين رده سلولى مربوط به سرطان بستان بوده كه داراى گيرندهاى استروزن إنى

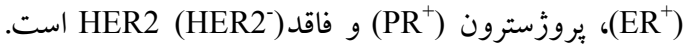
اين رده سلولى به استروزن حساس بوده و استروزن رسيتور
مقدمه

سرطان دومين عامل مرگك و مير در سراسر دنيا پِ از بيمارىهاى قلبى و عروقى بوده و در ميان انواع سرطان، سرطان بستان با نرخ سالانه // ميليون مورد جديد، نخستين بدخيمى در ميان زنان در سراسر دنيا برشمرده مى شود( ( ا ).). با وجود هبايينتر بودن ميزان ابتلا به اين بيمارى در ايران به نسبت ساير كشورهاى دنيا، به دليل ييخيرى دير هنگام درمان، آمار مر گكومير در اثر آن، به مراتب بالاست حرا كه ليه تعداد كثيرى از مبتلايان زمانى جهت درمان اقدام مىنمايند

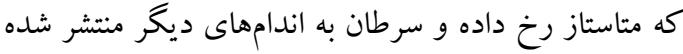
است(آو ).. به دليل غير انتخابى بودن شيمى درمانى و يرتو درمانى براى بافتها و سلولهاى درگير، درصد آسيب به ساير بخشها بالاست. به علاوه بروز مقاومت دارويى، از

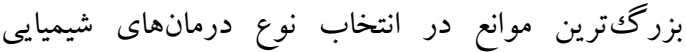

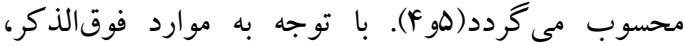
بررسى راه كارهاى جديد احتمالى جهت درمان، قابل توجه

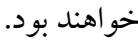
مهار كندههاى متاستاز گروهى از زنها هستند كه اكر جنانجه بيش از حد بيان شوند يا بيان مجدد داشته باشند، باعث مهار گسترش سرطان به ساير اندامها، بدون تأثير بر اندازه تومور اوليه مى گردند. همانند تشكيل تومور، هم مسيرهاى تحريكى و هم مهارى، متاستاز را تنظيم مىنمايند (9). بروتئين مهار كننده كيناز RKIP) Raf)، عاملى براى متعادل نمودن فعاليت كيناز بوده و از اين رو قادر است شر ايط سلول را تنظيم نمايد. به علاوه اين يروتئين قادر است

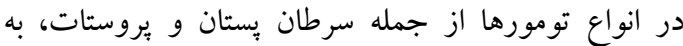
عنوان مهاركننده متاستاز وارد عمل شود. اين بروتئين سيتويلاسمى كوخجك، از يروتئينهاى متصل شونده به فسفاتيديل اتانل آمين است كه در اكثر گو نهاى بستانداران از قبيل انسان، موش و ميمون به صورت محافظت شده توليد مى گردد (V-q). بيان RKIP در تومورهاى بيش رفته كاهش مى يابد. مطالعات in vitro و در نمونهاى سرطان يُستان نشان داده كه اين يروتئين، 
درصد و اشعه UV استريل شده و داخل انكوباتور كشت

سلولى قرار داده شد. يس از شمارش سلولى توسط لام نئوبار، ". P× سلول MCF-7 به درون لولههاى مخصوص

(Tissue culture tube, TPP company, كشت سلول انتقال داده شد. پيس از ير شدن حدود ·لمwitzerland) Vر صد كف فلاسك توسط سلولها، محيط كشت لوله Vا خالى شده و با محيطى كه به منظور CO $\mathrm{CO}_{2}$ دار شدن، از شب قبل درون انكوباتور قرار گرفته بود ير گرديد. هدف از ير نمودن لولهها، جلو گيرى از حضور حباب و ايجاد نيروهاى برشى بر سلولها بود. لولهها در مر كز كلينواستت قرار گرفته و سرعت دستگاه بر روى •r دور در دقيقه تنظيم شد. در دو آزمون مجزا، لولههاى كشت كنترل (تحت جاذبه ا جى) و لولههاى كشت اصلى (تحت اثر بىوزنى)، به مدت ا شبانه روز و r شبانه روز كشت داده شدند( •Y). براى هر تست سه تكرار در نظر گرفته شد.

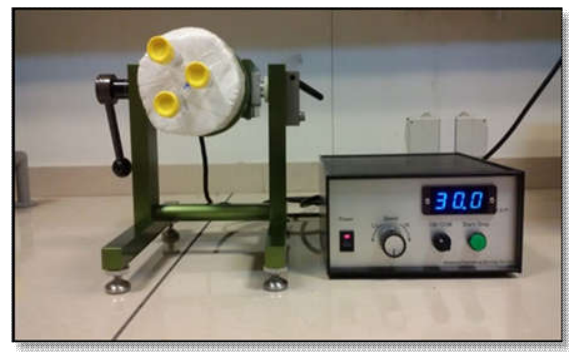

شكل ا. دستخاه كلينواست
آلفا (ERو از اين رو به منظور مطالعه مسير استروزن و توسعه درمانهاى سريع الاثر ضد هورمونى مانند تاموكسيفن، رده

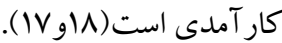

سلولها در محيط كشت Dulbecco's DMEM) 1. تكميل شده با modification of Eagle medium)

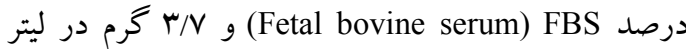
نمكك بى كربنات سديم و ا درصد از آنتى بيو تيككهاى ينى سيلين و استريتومايسين در فلاسككهاى كوجکك كشت سلول كشت داده شدند. سبس فلاسككها در انكوباتور درجه سانتى گراد، حاوى ه درصد جهت رشد قرار كرفتند. تمامى مواد ذكر شده جهت كشت CA, Gibco, Life Technologies Carlsbad, شر كت خريدارى شد. يس از اين كه •N-ASA فلاسك توسط سلولها ير گرديد، آنها را از كف جدا نموده و پياساز سلولى انجام شد. روش ياساز به اين نحو بود كه يس از خارج نمودن محيط كشت داخل فلاسك و شستشوى سلولها با محلول PBS، سلولها توسط محلول ه/ •درصد تريـسين -EDTA از كف فلاسـك كنده شده

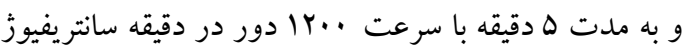
شـدند. قسمتى از رسوب سلولى به فلاسككهاى جديد انتقال داده شد و مازاد آن يس از افزودن FBS حاوى ·ل درصد Dimethyl sulfoxide) DMSO كرديد. انكوياسيون فلاسكها در شرايط ذكر شده انجام

كرديد (19).

القاى بىوزنى بر سلولها: به منظور القاى بىوزنى از

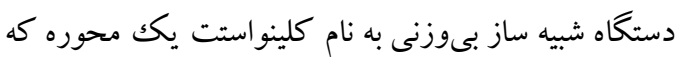
از دفتر سازمان ملل متحد در امور فضاى خارج از جو (United Nations Office at Vienna; The Office for (Outer Space Affairs) كرديد(شكل 1). روش كار اين دستخاه به اين طريق است كه با جرخاندن سلولها، قدرت دركك جاذبه را از آنها Vل سلب مىنمايد. از اينرو ابتدا كلينواستت توسط اتانل 
آكارز إه درصد بررسى گرديد. RNA هاى محصول تا

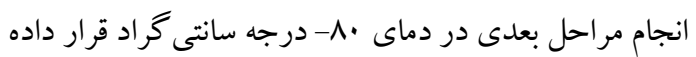
شدند. به منظور حذف آنزيم RNase، كليه وسايل و مواد

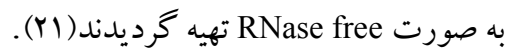
ساخت DNA) مكمل (Complementary DNA- cDNA) از روى الكوى : RNA : استخراج شده از سلولها، حاوى تمام RNA هاى سلولى از جمله mRNA،

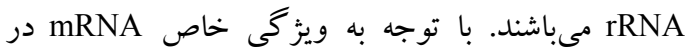
داشتن دنباله poly-A از آغازگر Oligo-T در ساخت

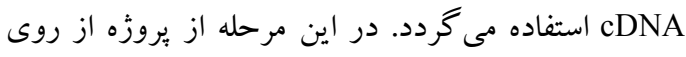

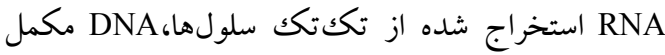
cDNA ساخته شد. به اين منظور، از كيت سنتز التهرا (cDNA)

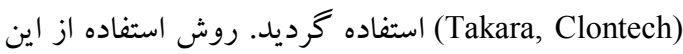
كيت شامل دو مرحله بود به اين صورت كه ابتدا r

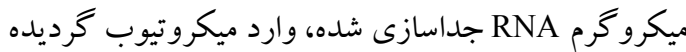
و سبس يرايمر Oligo-dT، بافر مربوطه و آنزيم نسخهبردار

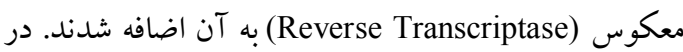
مرحله دوم، نمونه به مدت ها دقيقه در دماى TV درجه

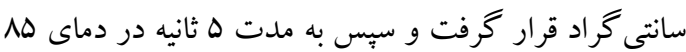

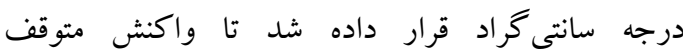

$$
\text { كردد) (Y) }
$$

طراحى يرايمر و تائيد آن: طراحى يرايمر براى زنهاى GAPDH

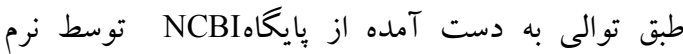

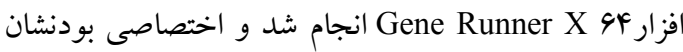

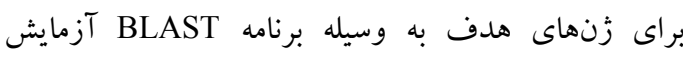
كرديد. سبس جهت سنتز به شركت زيست فناورى بيشكام سفارش داده شد. در اين مطالعه زن مرد

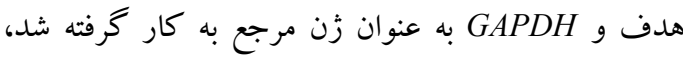

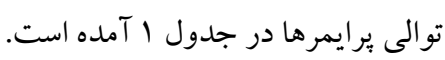

تخليص RNA از سلولها: به منظور بررسى برخى تغييرات زرنتيكى حادث شده در سلولها پِ از اعمال بى وزنى، از

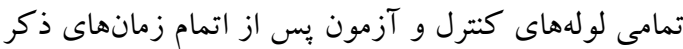
شده، RNA كل جداسازى گرديد. جهت تخليص، محلول RNX-PLUS شر كت سازنده به كار رفت. بدين منظور، ابتدا محتواى هر يك از لولهها به مدت ه دقيقه در ..rا دور در دقيقه سانتريفيوز شده و پِ از دور ريختن محلول رويى، به ميزان ا ميلى ليتر از محلول RNX-PLUS سرد، به هر لوله افزوده و يس از مخلوط نمودن كامل با سلولها، كل محتواى لوله

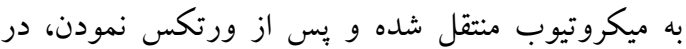

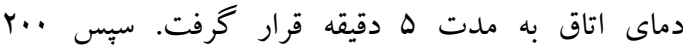

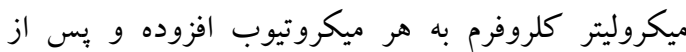
مخلوط نمودن، به مدت ه دقيقه در دماى F أ درجه

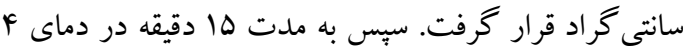

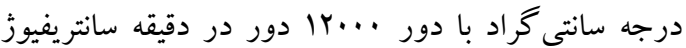
كرديد. در مرحله بعد، فاز آبى (رويى) به ميكروتيوب جديد

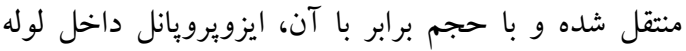
ريخته شده و به خوبى مخلوط شد. بِ از قرار دادن بر روى برى

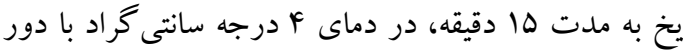
Ir.... محلول رويى دور ريخته شده و ml ا اتانل VD درصد بر روى رسوب ريخته و پِ از ورتكسى كوتاه، 1 دقيقه در دماى F درجه سانتى گراد با دور ل. VQ دور در دقيقه

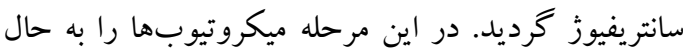

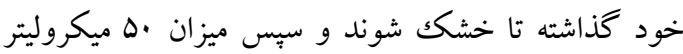
آب فاقد RNase درون هر تيوب ريخته شد و به مدت . دقيقه در دماى •9-هه درجه سانتى گراد قرار داده شد. غلظت و ميزان خلوص RNA با استفاده از دستكاه

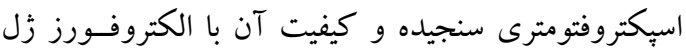




\begin{tabular}{|c|c|c|}
\hline \multicolumn{3}{|c|}{ جدول ا. آغاز گرهاى اليكو نو كلئوتيدى سنتز شده جهت PCR } \\
\hline 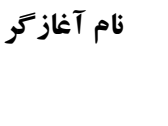 & توالى آغازكر & (جفت باز) \\
\hline GAPDH F & 5'ACGACCACTTTGTCAAGCTCAT3' & \\
\hline GAPDH R & 5'TCCACCACCCTGTTGCTGTA3' & $9 \mathrm{~V}$ \\
\hline RKIP F & 5'CAATGACATCAGCAGTGGCACAGTC3' & \\
\hline RKIP R & 5'ACATAGTCATCCCACTCGGCCTG3' & req \\
\hline
\end{tabular}

premix Ex taqII

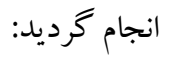

در جاهك يليت مخصوص Real time PCR مخلوطى با رديل:

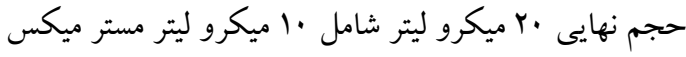

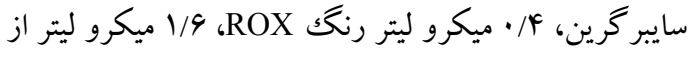

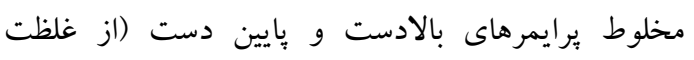

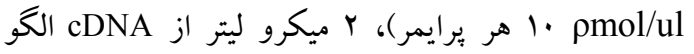
مربوطه و 4 ميكرو ليتر آب مقطر تهيه شد. بس از از آماده

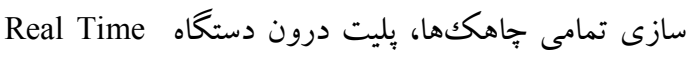

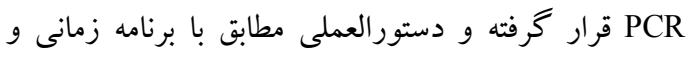

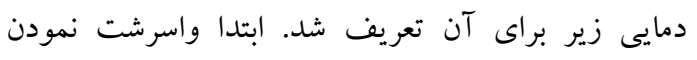

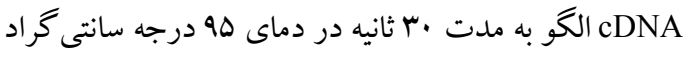

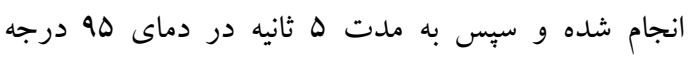

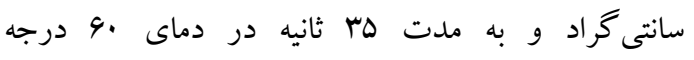

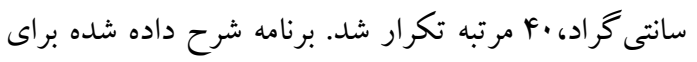
هر نمونه CDNA انجام شده و Ct براى هر كدام محاسبه

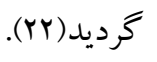

تجزيه و تحليل آمارى دادهها: دادهها به صورت ميانگين

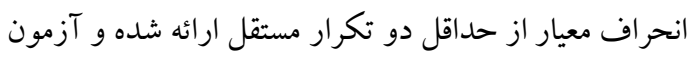
t-test

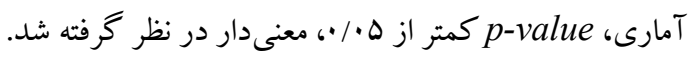

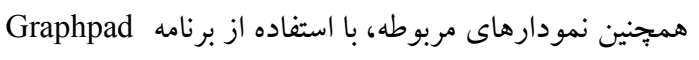

$$
\text { prism } 7
$$

جهت تائيد برايمرها، PCR معمولى به شرح ذيل انجام

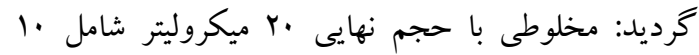

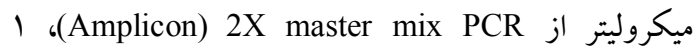
ميكروليتر از هر يكك از برايمرهاى بالادست و بايين دست

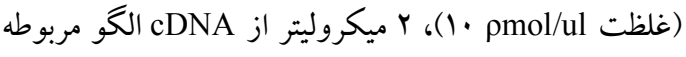
ساختهده و و ميكروليتر آب مقطر تهيه شد. بعد از آمادهسازى مخلوط واكنش، درون دستكاه ترموسايكلر

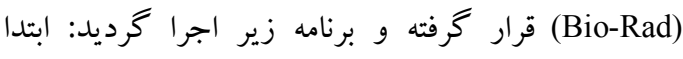

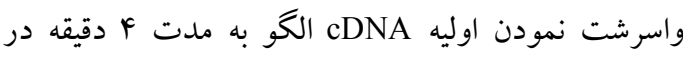

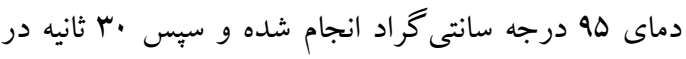

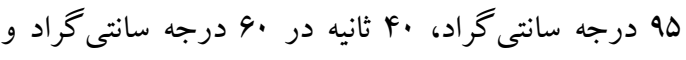

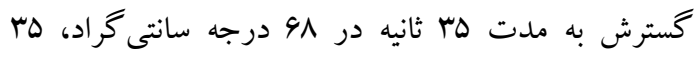

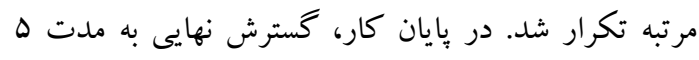

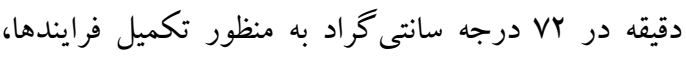

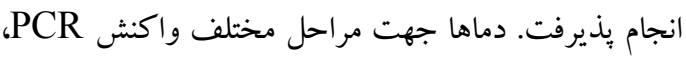

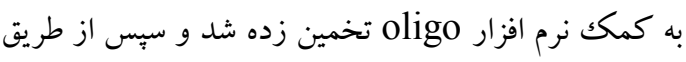

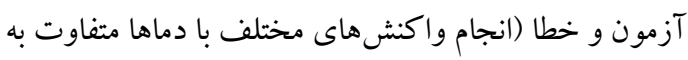

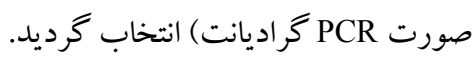

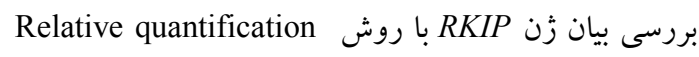
(qRT-PCR) Real time PCR وسيله دستگاه Bio- Step One Plus Real Time PCR SYBR (Takara, Clontech) با كيت Rad, USA) 
شدند. شكل r تصوير اين سلولها را در محيط كشت نشان

كشت سلولى پس از تهيه رده سلولى MCF-7، در شرايط كاملاً استريل در محيط كشت DMEM كشت و تكثير

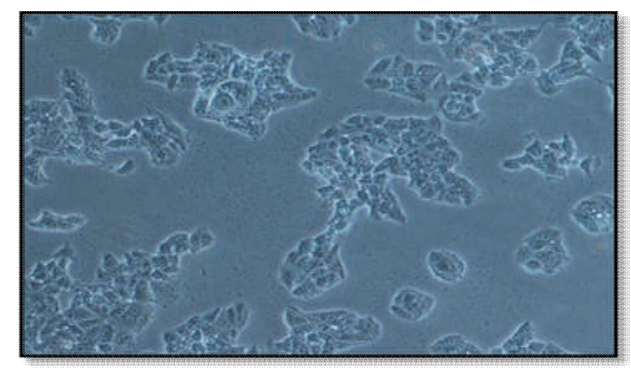

شكل r. رده سلولى MCF-7 سرطان يستان

سنجش كميت و كيفيت RNAهاى تخليص شده: به منظور حصول اطمينان از عدم تجزيه RNA هاى استحصال شده،

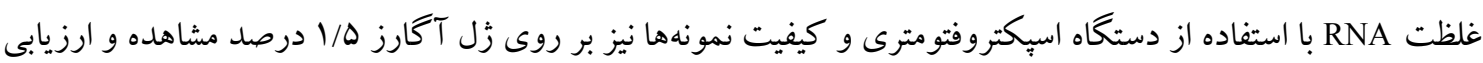

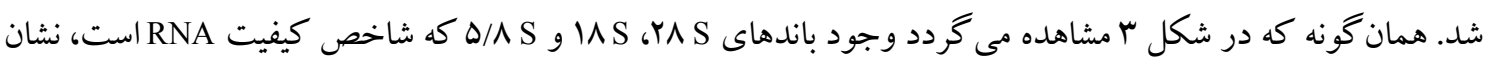
دهنده استخراج صحيح آن است(شكل r). mRNA به صورت اسمير از بالا تا يايين قابل مشاهده است. نتايج حاصله نشان دهنده اين بودند كه RNA استحصالى را مىتوان با اطمينان در مر احل بعدى مطالعه مورد استفاده قرار داد. 


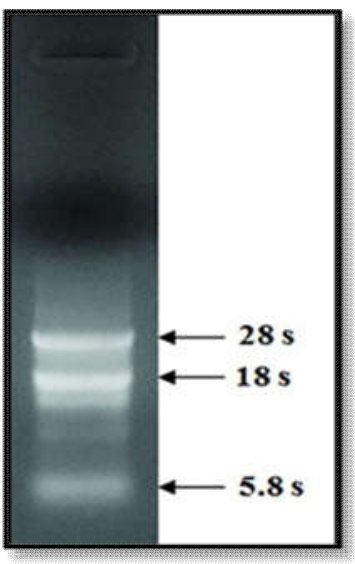

شكل r. بررسى كيفيت RNA كل استحصال شده از سلولهاى MCF-7

تائيد يرايمرهاى ساخته شده: يس از ساختن CDNA معمولى به منظور تائيد برايمرها انجام شد و نتايج بر زل T آكارز 1/ درصد مشاهده شدند. حضور دو باند 9V و FFq جفت بازى، تائيد نمودند كه يرايمرها به خوبى به زنهاى RAPDH RKIP متصل شده و تكثير اين دو زن با موفقيت

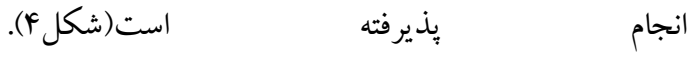

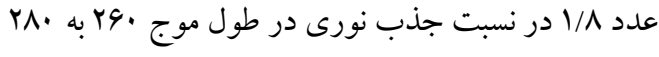
نانومتر در بررسى با اسپكتروفوتومتر نيز نشان دهنده درجه خلوص بالاى نمونه بود. به طور كلى، نتايج نشان دادند كه RNA تخليص شده در مرحله بعدى با اطمينان كامل، قابل كاربرد است.

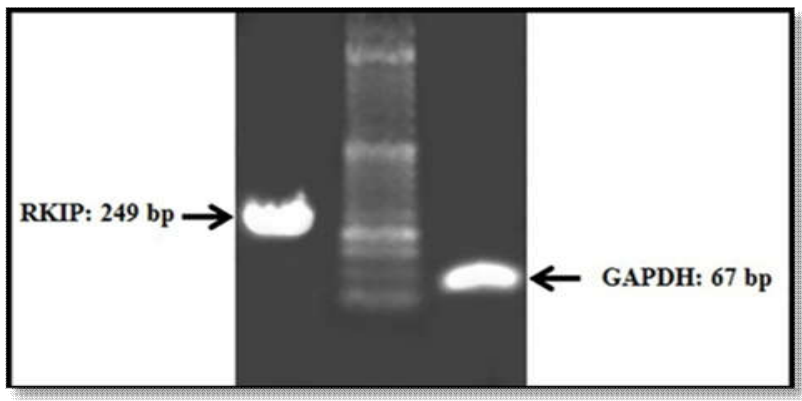

شكل f. نتايج تكثير بخشى از زنهاى GAPDH و RIP رديف ميانى، ماركر مولكولى •ه جفت باز. 
تيمارهاى مختلف در رده سلولى مذكور است (سY). جهت

تائيد نمودن صحت قطعات تكثيرى و اطمينان از عدم وجود

محصول غير اختصاصى، نمودار ذوب (Melting curve) بررسى كرديد كه وجود تنها يكك قله (Peak) در اين نوع نمودار براى هر زن در دماى ذوب ويزه خود، مؤيد اختصاصى بودن محصول PCR است(شكل ه).
بررسى تغييرات بيانى زن RKIP در سلولها: جهت بررسى qRT- ميزان بيان زُن مهار كننده متاستاز RKIP، واكنشى PCR مشابه بر رده سلولى MCF-7، زن GAPDH به عنوان يكى از مناسبترين زنها جهت كنترل داخلى انتخاب كرديد، جرا كه به صورت دائمى، داراى ثبات بيان زن حتى در

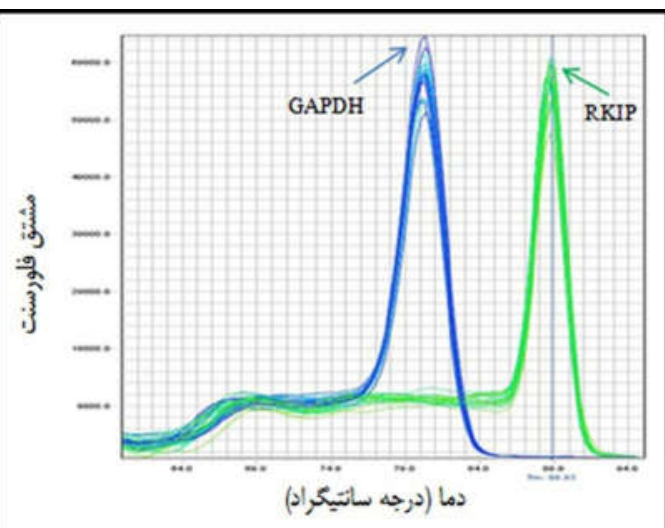

شكل ه. منحنى هاى ذوب زٔنهاى مورد مطالعه در آزمون Real Time PCR براى زن مرجع GAPDH و زن مورد مطالعه RKIP. تنها يك قله در دماى ذوب ويزٔه براى هر زن، اختصاصى بودن محصول را ثابت نمود.

بر اساس اطلاعات حاصله از واكنش qRT-PCR، در نمونه هايى كه به مدت بF ساعت تحت شرايط نبود جاذبه كشت داده شده بودند، نسبت به نمونه هاى كنترل (شرايط g ()، سطح بيان زن RKIP به طور معنى دارى افزايش يافته بود (ه •/•> p ). با طولانى تر نمودن زمان اعمال بىوزنى تا VY ساعت، بيان زن هدف كاهش يافته و به سطح كنترل باز گشت (شكل 9). 


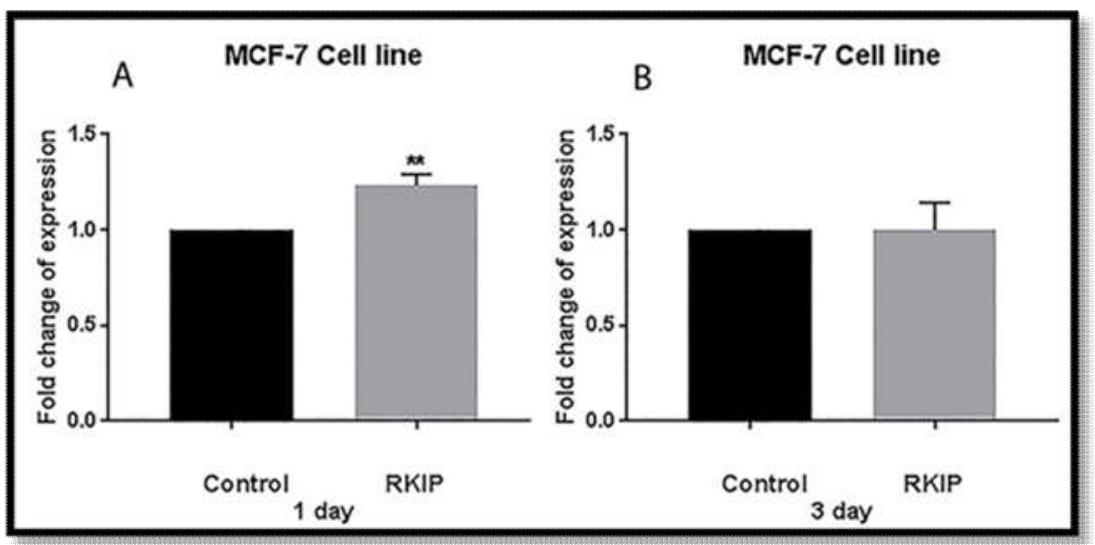

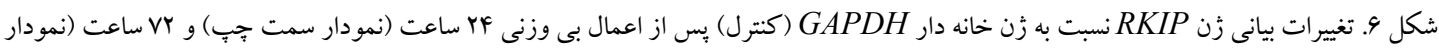
سمت راست) در واكنش q*P<

استرس، تغيير الكوهاى تذيهاى، اضافه وزن اشاره نمود(YN). به دليل هتروزن بودن بالاى سرطان يستان و قابليت متاستاز آن به برخى اندامها، همجنين عدم شفافيت

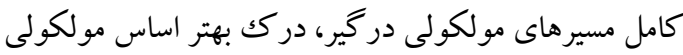
متاستاز و بررسى تأثيرات عوامل مختلف در بيشخيرى از وقوع آن، منجر به بهبود و گسترش روشهاى نوين درمانى

$$
\text { خو اهد كرديد. }
$$

يروتئينهاى مهار كننده متاستاز گروهى از يروتئينهاى درونسلولى هستند كه در مراحل مختلف فرايند متاستاز نقش آفرينى مى كنند. شناخت اين يروتئينها و فهم

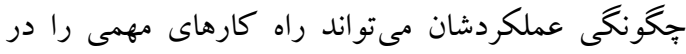
مورد كنترل فرايند بييجيده متاستاز ارائه دهد( هو 9). بروتئين يكى از مهار كنندههاى اميد بخش متاستاز است كه RKIP اعمال فيزيولوزيكك مختلفى دارد. در ارتباط با نقش مهار كنداكى متاستاز براى اين پروتئين، تحقيقاتى جند انجام يذيرفته است. Zheng و همكاران در سال ب. .ب نشان دادند كه اين پيروتئين در يكك مدل زنو كرافت (ييوند از گونهاى به كونه ديخر) موشى مربوط به سرطان بروستات، به عنوان مهار كننده متاستاز عمل نموده است(؟)). علاوه بر اين گروه تحقيقاتى Dangi-Garimella در ه ه . .ب ثابت نمودهاند كه افزايش بيان يروتئين RKIP از بيشرفت متاستازى مدل در اين مطالعه براى نخستين بار به بررسى تغييرات حادث شده بر بيان زن مهار كننده متاستاز RKIP ، در سلولهاى رده سرطان يستان كه به مدت MCF-7 بىوزنى شبيه سازى شده قرار گرفته بودند، يرداختيم جرا كه تأثير حذف جاذبه، هم به صورت شبيه سازى شده و هم واقعى، در مطالعاتى جند بر بيان برخى زنها و تغيير محتواى

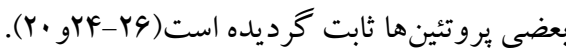
سرطان از جمله بيمارىهاى مزمن و غير واگيرى است كه طيف وسيعى از بيمارىها را شامل مىشود و اين بيمارى نيز همانند ساير بيمارىهاى مزمن، ممكن است در هر فرد با هر سن و هر نزادى رخ داده و از اين رو از مهمترين معضلات عمده بهداشت و سلامت در تمامى جوامع در نظر كرفته مىشود(YV). با توجه به آمارهاى ارائه شده از كسترش

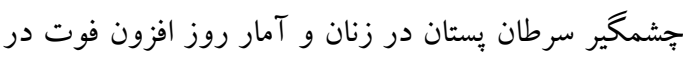
اثر اين بيمارى و همجنين وقوع متاستاز آن به ساير نقاط بدن، توجه يزو هشخران به راه كارهاى نوين در بيش آكهى و جلو گيرى از مرگك و مير در اثر اين بيمارى معطوف گرديده است. از عوامل مرتبط با شيب صعودى مبتلايان به اين نوع سرطان، مىتوان به داشتن سابقه فاميلى، آلودگى هوا، تغيير الكوى زندگى، عدم فرزند آورى يا به تعويق انداختن آن، 
و همكاران ، ثابت نمودند كه قرار دادن رده سلولى MCF-7 سرطان بِتان در شر ايط بى وزنى واقعى، بيان بسيارى از زنها دستخوش تغييرات نموده است به نحوى كه برخى دجار افزايش و برخى دجار كاهش بيان گرديده و البته برخى بدون تغيير باقى ماندند(ه)). در يك نكاه كلى، مقاله مرورى

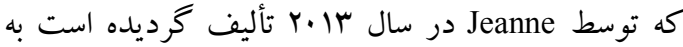
مواردى جند از تغييرات بيان زنها تحت اعمال بى وزنى

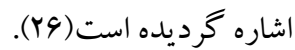

سلولهاى MCF-7 كه سطوح بايينى از تهاجم را نشان مى - دهن دهند در زيرگروه لومينال قرار داشته و داراى گيرنده استروزن و يروزسترون است و از اين رو به درمانهاى

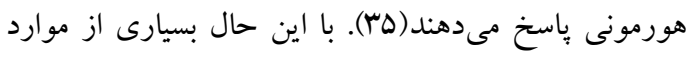

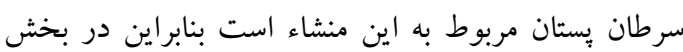

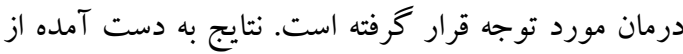
اين بروزه نشان دادند كه بس از قرار دادن سلولها به مدت

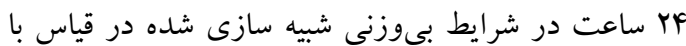
نمونههاى كنترل، به طور معنى دارى شاهد افزايش بيان زن

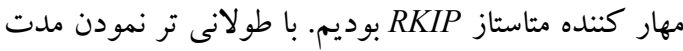
زمان بى وزنى شبيهسازىشده تا VY ساعت، تغييرات بيان معنى دارى نسبت به نمونههاى كنترل ملاحظه نشد؛ به

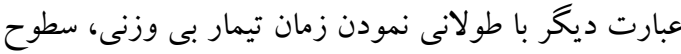

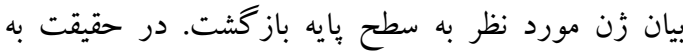

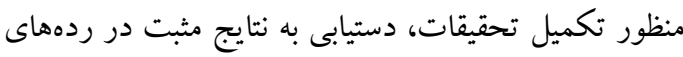

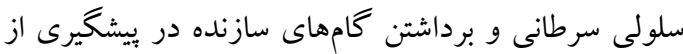

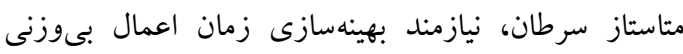

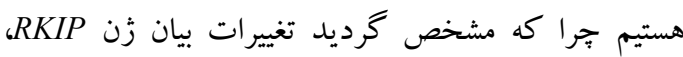

$$
\text { وابسته به الخوى زمانى است. }
$$

\section{نتيجه كيرى}

با توجه به آمار رو به رشد سرطان بِّتان و مرك و مير در اثر متاستاز آن به ساير اندامها، مقاومتهاى دارويى به انواع درمانها و همجينين اثرات ناخواسته درمانها به سلولهاى سالم بدن، نياز به روشهاى نوين درمانى در اين حيطه كاملاً
زنو گرافت سرطان سينه به استخوان ممانعت به عمل آورده است(•(1). در مطالعهاى نشان داده شده كه در مدل موشى، برقرارى مجدد بيان زن RKIP، براى مهار متاستاز سرطان

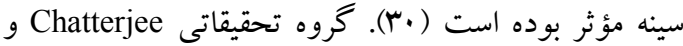
همكاران نيز نشان دادند كه تحريك خارجى براى افزايش بيان RKIP، باعث تحريك آسيب DNA و القاى آيويتوز سلولهاى سرطانى خواهد شد(آ). همجِنين ثابت شده است قدرت مهاجرت سلولى و بقاى آن در آزمايشگاه با كاهش بيان RKIP افزايش يافته است(م). با توجه به اهميت بروتئين RKIP در ممانعت از متاستاز سرطان به ساير اندامهاى بدن، همجنين قابليت اعمال بى وزنى در تغييرات بيان زنها، جنانجه بى وزنى قادر به افزايش بيان اين يروتئين گردد، افقهاى نوينى را در مبارزه با بيمارى كشنده سرطان و ممانعت از متاستاز آن به ساير بافتها خواهد گشود. موجودات زنده ساكن بر روى كره زمين تحت نيروى

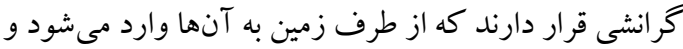
اين نيرو بر روند تكامل و فيزيولوزى موجود و همجِنين بر بروز زنها و عملكرد سلولها تأثير كذار است(بس). با توجه به مشكلات و هزينهاى بالاى مطالعات در شرايط بى وزنى واقعى، دستگاههايى خند براى خنثى سازى بى وزنى طراحى

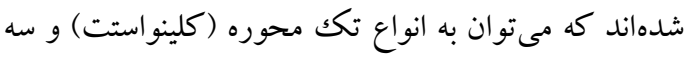

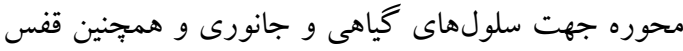

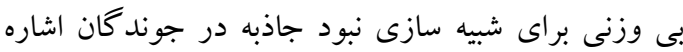
نمود(باو بr). در اين بروزه به منظور شبيه سازى بى وزنى، دستخاه كلينواستت تكك محوره به كار رفت. بر اساس تحقيقات انجام بذيرفته توسط Lin و همكاران، بىوزنى شبيه سازى شده، خودكشى سلولى را در سلولهاى

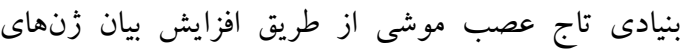

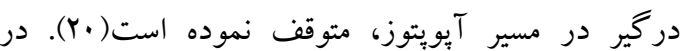

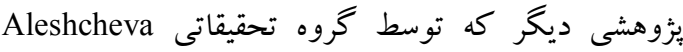

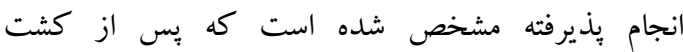
كندريوسيتهاى انسانى در بى وزنى، بيان زن و محتواى يروتئينى TGF-B1 افزايش يافته است(YF). همجنين Nassef 


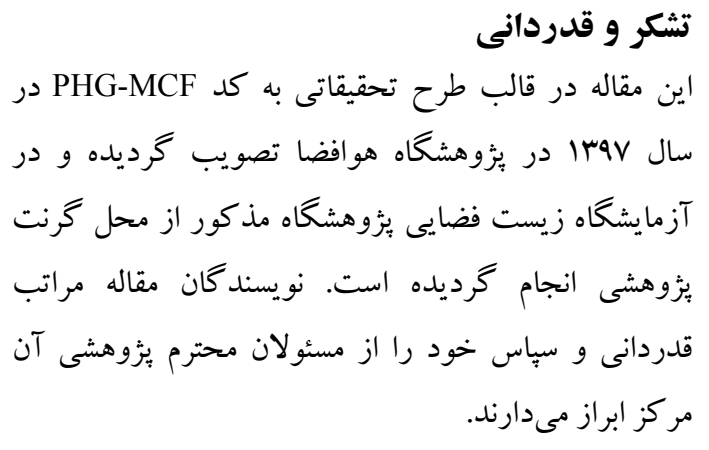

$$
\begin{aligned}
& \text { محسوس است. با استناد به نتايج حاصله به نظر مىرسد } \\
& \text { روش حذف جاذبه، روشى مؤثر جهت افزايش بيان زُن مهار } \\
& \text { كننده متاستاز RKIP بوده اما بهينه سازى زمان اعمال اين } \\
& \text { شرايط بر سلول در تحصيل نتايج سازنده، لازم الاجرا است. } \\
& \text { از اين رو اميد است با مطالعه بيشتر اثر حذف نيروى جاذبه بر }
\end{aligned}
$$

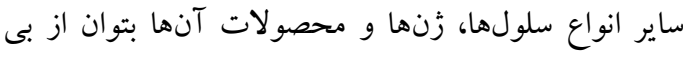

$$
\begin{aligned}
& \text { وزنى به عنوان روشى درمانى و يِيشير انه در مقوله سرطان و }
\end{aligned}
$$

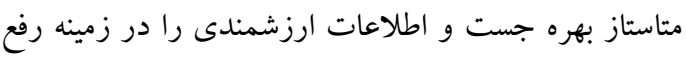

$$
\begin{aligned}
& \text { ابهامات علوم زيستى به ارمغان آورد. }
\end{aligned}
$$

\section{References}

1. DeVita VT, Lawrence TS, Rosenberg SA, editors. DeVita, Hellman, and Rosenberg's cancer: principles \& practice of oncology. Lippincott Williams \& Wilkins; 2008.

2. Weiderpass E, Labrèche F. Malignant tumors of the female reproductive system. InOccupational Cancers 2014 (pp. 409-422). Springer, London.

3. Rajaee M, Zare S, Dadipour S, Fallahi S, Rajaee F, Mobarakabadi A, et al. Determining the frequency and causes of maternal mortality in hormozgan province, Iran during 2005-2011. The Iranian Journal of Obstetrics, Gynecology and Infertility. 2014;16(87):9-14.

4. Sabzichi M, Hamishehkar H, Ramezani F, Sharifi S, Tabasinezhad M, Pirouzpanah M, et al. Luteolin-loaded phytosomes sensitize human breast carcinoma MDA-MB 231 cells to doxorubicin by suppressing Nrf2 mediated signalling. Asian Pacific Journal of Cancer Prevention. 2014;15(13):5311-6.

5. Willers H, Azzoli CG, Santivasi WL, Xia F. Basic mechanisms of therapeutic resistance to radiation and chemotherapy in lung cancer. Cancer journal (Sudbury, Mass.). 2013 May;19(3):200.

6. Khan I, Steeg PS. Metastasis suppressors: functional pathways. Laboratory Investigation. $2018 \mathrm{Feb} ; 98(2): 198$.

7. Wottrich S, Kaufhold S, Chrysos E, Zoras O, Baritaki S, Bonavida B. Inverse correlation between the metastasis suppressor RKIP and the metastasis inducer YY1: Contrasting roles in the regulation of chemo/immuno-resistance in cancer. Drug Resistance Updates. 2017 Jan $1 ; 30: 28-38$.

8. Escara-Wilke J, Yeung K, Keller ET. Raf kinase inhibitor protein (RKIP) in cancer. Cancer and Metastasis Reviews. 2012 Dec 1;31(3-4):615-20.

9. Yesilkanal AE, Rosner MR. Raf kinase inhibitory protein (RKIP) as a metastasis suppressor: regulation of signaling networks in cancer. Critical Reviews ${ }^{\mathrm{TM}}$ in Oncogenesis. 2014;19(6).

10. Birner P, Jesch B, Schultheis A, Schoppmann SF. RAF-kinase inhibitor protein (RKIP) downregulation in esophageal cancer and its metastases. Clinical \& experimental metastasis. 2012 Aug 1;29(6):551-9.

11. Yousuf S, Duan M, Moen EL, Cross-Knorr S, Brilliant K, Bonavida B, et al. Raf kinase inhibitor protein (RKIP) blocks signal transducer and activator of transcription 3 (STAT3) activation in breast and prostate cancer. PLoS One. 2014 Mar 21;9(3):e92478.

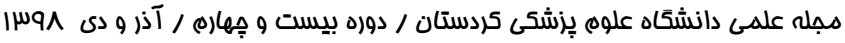


عاه تاثير بى وزنى بر بيان...

12. Prat A, Karginova O, Parker JS, Fan C, He X, Bixby L, et al. Characterization of cell lines derived from breast cancers and normal mammary tissues for the study of the intrinsic molecular subtypes. Breast cancer research and treatment. 2013 Nov 1;142(2):237-55.

13. Yamamoto M, Hosoda M, Nakano K, Jia S, Hatanaka KC, Takakuwa E, et al. p53 accumulation is a strong predictor of recurrence in estrogen receptor-positive breast cancer patients treated with aromatase inhibitors. Cancer science. 2014 Jan;105(1):81-8.

14. Rea G, Cristofaro F, Pani G, Pascucci B, Ghuge SA, Corsetto PA, et al. Microgravitydriven remodeling of the proteome reveals insights into molecular mechanisms and signal networks involved in response to the space flight environment. Journal of proteomics. 2016 Mar 30;137:3-18.

15. Versari S, Longinotti G, Barenghi L, Maier JA, Bradamante S. The challenging environment on board the International Space Station affects endothelial cell function by triggering oxidative stress through thioredoxin interacting protein overexpression: the ESASPHINX experiment. The FASEB Journal. 2013 Nov;27(11):4466-75.

16. Maier JA, Cialdai F, Monici M, Morbidelli L. The impact of microgravity and hypergravity on endothelial cells. BioMed research international. 2015;2015.

17. Herranz R, Anken R, Boonstra J, Braun M, Christianen PC, de Geest M, et al. Groundbased facilities for simulation of microgravity: organism-specific recommendations for their use, and recommended terminology. Astrobiology. 2013 Jan 1;13(1):1-7.

18. Dadgarnia H, Hajebrahimi Z. The Effect of Microgravity Condition on Expression of VEGFR-2 Gene in Human Umbilical Vein Endothelial Cells (HUVEC). Journal of Arak University of Medical Sciences. 2016 May 10;19(2):26-34.

19. Freshney RI. Culture of animal cells: a manual of basic technique and specialized applications. John Wiley \& Sons; 2015 Dec 23.

20. Lin SC, Gou GH, Hsia CW, Ho CW, Huang KL, Wu YF, et al. Simulated microgravity disrupts cytoskeleton organization and increases apoptosis of rat neural crest stem cells via upregulating CXCR4 expression and RhoA-ROCK1-p38 MAPK-p53 signaling. Stem cells and development. 2016 Jun 6;25(15):1172-93.

21. Hassanzadeh K, Nikzaban M, Moloudi MR, Izadpanah E. Effect of selegiline on neural stem cells differentiation: a possible role for neurotrophic factors. Iranian journal of basic medical sciences. 2015 Jun;18(6):549.

22. Jensen EC. Real-Time Reverse Transcription Polymerase Chain Reaction to Measure mRNA: Use, Limitations, and Presentation of Results. The Anatomical Record: Advances in Integrative Anatomy and Evolutionary Biology. 2012 Jan;295(1):1-3.

23. Liu LL, Zhao H, Ma TF, Ge F, Chen CS, Zhang YP. Identification of valid reference genes for the normalization of RT-qPCR expression studies in human breast cancer cell lines treated with and without transient transfection. PloS one. 2015 Jan 24;10(1):e0117058.

24. Aleshcheva G, Sahana J, Ma X, Hauslage J, Hemmersbach R, Egli M, et al. Changes in morphology, gene expression and protein content in chondrocytes cultured on a random positioning machine. PLoS One. 2013 Nov 11;8(11):e79057.

25. Nassef MZ, Kopp S, Wehland M, Melnik D, Sahana J, Krüger M, et al. Real Microgravity Influences the Cytoskeleton and Focal Adhesions in Human Breast Cancer Cells. International journal of molecular sciences. 2019 Jan;20(13):3156.

26. Becker JL, Souza GR. Using space-based investigations to inform cancer research on Earth. Nature Reviews Cancer. 2013 May;13(5):315.

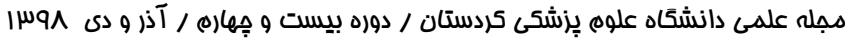


27. Siegel R, Ward E, Brawley O, Jemal A. Cancer statistics, 2011: the impact of eliminating socioeconomic and racial disparities on premature cancer deaths. CA: a cancer journal for clinicians. $2011 \mathrm{Jul} ; 61(4): 212-36$.

28. Onsory K, Ranapoor S. Breast cancer and the effect of environmental factors involved. New Cellular and Molecular Biotechnology Journal. 2011 Oct 15;1(4):59-70.

29. Fu Z, Smith PC, Zhang L, Rubin MA, Dunn RL, Yao Z, et al. Effects of raf kinase inhibitor protein expression on suppression of prostate cancer metastasis. Journal of the National Cancer Institute. 2003 Jun 18;95(12):878-89.

30. Beshir AB, Ren G, Magpusao AN, Barone LM, Yeung KC, Fenteany G. Raf kinase inhibitor protein suppresses nuclear factor- $\kappa B$-dependent cancer cell invasion through negative regulation of matrix metalloproteinase expression. Cancer letters. 2010 Dec 28;299(2):137-49.

31. Chatterjee D, Yuan Z, Bonavida B, Darnowski J, Chin YE. RKIP inhibits IL-6-mediated activation of Stat 3 in DU145 prostate cancer cells.

32. Winnard A, Nasser M, Debuse D, Stokes M, Evetts S, Wilkinson M, et al. Systematic review of countermeasures to minimise physiological changes and risk of injury to the lumbopelvic area following long-term microgravity. Musculoskeletal Science and Practice. 2017 Jan 1;27:S5-14.

33. Jamon M. The development of vestibular system and related functions in mammals: impact of gravity. Frontiers in integrative neuroscience. $2014 \mathrm{Feb}$ 7;8:11.

34. Aleshcheva G, Bauer J, Hemmersbach R, Egli M, Wehland M, Grimm D. Tissue engineering of cartilage on ground-based facilities. Microgravity science and technology. 2016 Jun 1;28(3):237-45.

35. Holliday DL, Speirs V. Choosing the right cell line for breast cancer research. Breast cancer research. 2011 Aug;13(4):215. 